\title{
Motor Nuclei of Medulla Oblongata in the European Bison
}

\author{
Stanisław SZTEYN, Edward SZATKOWSKI \& Barbara JATCZAK
}

Szteyn S., Szatkowski E. \& Jatczak B., 1985: Motor nuclei of medulla oblongata in the European bison. Acta theriol. 30, 25: 423-433, 1985 [With Plates VII-VIII]

A description is given in respect of 4 European bison, Bison bonasus (Linnaeus, 1758) from the Białowieża Primeval Forest, of the position, formation and cell structure of the motor nuclei of medulla oblongata: nuc. $n$. accessorii, nuc. n. hypoglossi, nuc. sublingualis sympathicus, nuc. intercalatus Staderini, nuc. praepositus Marburgi, nuc. paramedianus dorsalis, nuc. parasympathicus dorsalis nn. IX et $\mathrm{X}$, nuc. ambiguus, nuc. n. facialis, nuc. n. abducentis, nuc. motorius n. trigemini and nuc. subtrigeminalis.

[Teachers Training College, Department of Vertebrates Anatomy, Zołnierska St., 14, 10-561 Olsztyn, Poland].

\section{INTRODUCTION}

The purpose of this study was to determine the position, formatioin and cytoarchitectonics of the motor nuclei of medulla oblongata in the European bison, Bison bonasus (Linnaeus, 1758), in view of the lack of such data in literature. These nuclei have, however, been described in certain other representatives, both wild and domesticated, of Artiodactyla. Such studies have been made, inter alia, by Chomiak (1951, 1954), Fiedoruk (1975), Goller (1965), Strzałka \& Flieger $(1979,1982)$ and Welento $(1955,1956)$. In addition Zioło (1957) and Welento (1965) examined the development of motor nuclei during the ontogenetic development of pigs. A considerable amount of data is to be found in literature on motor nuclei of medulla oblongata in mammals belonging to other orders, which have made their comparison with the results of the present study possible.

\section{MATERIAL AND METHODS}

Studies were made on the medullae oblongatae of 4 European bisons from the Białowieża Primeval Forest. The material was fixed in formalin, dehydrated in ethyl alcohol and embedded in paraffin. The brains were sectioned to $15 \mu \mathrm{m}$, and every second section was taken for examination. The sections were stained with Löffler methyl blue after Nissl, and with cresyl wiolet and luxol fast blue after Klüver and Barrera. The abbreviations given in the captions to Plates have been used in the text of this paper. 


\section{RESULTS}

Nucleus n. accessorii, Nac (Photos. 1, 9, 10)

Nucleus n. accessorii in the European bison is situated in the cervical part of the spinal medulla and the posterior part of medulla oblongata. The anterior part of this nucleus, situated in medulla oblongata, has been described in this paper.

The part of Nac lying in medulla oblongata is formed of two bands of cells, which in cross-sections appear in the form of two groups: dorsal and ventral.

The dorsal group lies laterally and slightly dorsal from the central canal (cc). In longitudinal sections it exhibits numerous narrowings similar in shape to a string of beads. In cross-sections the dorsal group, in well-developed places, takes on the form of a horizontal oval which for short distances divides into subgroups: medial and lateral. The dorsal group disappears about $100 \mu \mathrm{m}$ to the rear of the posterior pole cf $\mathrm{Np}$.

The ventral group of Nac lies laterally and slightly below cc. There are numerous narrowings in its course, similar to those in the dorsal group. In cross-sections, in well-developed places, it appears as an oval formed of loosely arranged cells. The ventral band disappears at the level of the posterior pole of $\mathrm{Np}$.

The dorsal band of $\mathrm{Nac}$ is formed by fusiform cells measuring $55-85 \mu \mathrm{m}$ along the long axis and a small number of multipolar cells measuring $30-40 \mu \mathrm{m}$. The ventral band consists of multipolar cells measuring $35-45 \mu \mathrm{m}$ and a small number of rounded cells measuring $20-25 \mu \mathrm{m}$. A large light-staining nucleus occurs in the cells, and a large amount of coarse-grained tigroid substance.

Nucleus n. hypoglossi, Nh (Photos 2, 11)

Nucleus $n$. hypoglossi in the European bison lies in the extraventricular part of medulla oblongata (about $3 / 7$ of the posterior part) and on the floor of ventricle IV (about $4 / 7$ of the anterior part). The posterior pole of this centre lies at the level of the posterior pole of nucleus olivaris inferior. The anterior pole of $\mathrm{Nh}$ is situated about $270 \mu \mathrm{m}$ to the rear from the anterior pole of nucleus olivaris inferior. Nh is approximately $12 \mathrm{~mm}$ in length.

The posterior part of $\mathrm{Nh}$ lies laterally and slightly below cc. In its middle part the nucleus approaches the raphe and is adjacent on the dorsolateral side to nucleus intercalatus Staderini (Ni) and on the ventral side to nucleus sublingualis sympathicus $(\mathrm{Nr})$. The anterior part of $\mathrm{Nh}$ is further away from the raphe and is adjacent on the dorsomedial side 
to nucleus praepositus Marburgi $(\mathrm{Nm})$ and on the dorsolateral side is still adjacent to $\mathrm{Ni}$.

The anterior and posterior part of $\mathrm{Nh}$ are compact clusters of cells. In the middle part (from $1 / 6$ of the posterior to $1 / 5$ of the anterior part) the nucleus divides into two and then into three groups of cells: the medial, lateral and dorsal. The medial group is far more strongly developed than the other two groups.

$\mathrm{Nh}$ is formed of multipolar cells measuring $60-80 \mu \mathrm{m}$ and a few fusiform cells measuring 50-70 $\mu \mathrm{m}$ along the long axis, and rounded cells measuring $20-30 \mu \mathrm{m}$. The cells contain a large lightstaining nucleus with a centrally positioned nucleolus and a large amount of coarse-grained tigroid substance.

Nucleus sublingualis sympathicus s. Rolleri, Nr (Photos. 2, 12)

$\mathrm{Nr}$ lies in the extraventricular part of medulla oblongata $(2 / 7$ of the posterior parts) and on the floor of ventricle IV (5/7 of the anterior parts). The posterior end of $\mathrm{Nr}$ lies about $1 \mathrm{~mm}$ to the rear of calamus scriptorius. Its anterior end is situated at the level of the posterior pole of $\mathrm{Nm}$. $\mathrm{Nr}$ is about $4 \mathrm{~mm}$ long. $\mathrm{Nr}$ lies ventrally from $\mathrm{Nh}$. Seen in cross-section it consists of a small group of cells of approximately oval shape. $\mathrm{Nr}$ consists of fusiform cells measuring $25-35 \mu \mathrm{m}$ along the long axis and rounded cells measuring $17-20 \mu \mathrm{m}$. The cells contain a large, light-staining nucleus with a centrally positioned nucleolus and a few grains of tigroid substance.

Nucleus intercalatus Staderini, Ni (Photos. 2, 13)

$\mathrm{Ni}$ lies on the floor of ventricle IV. The posterior pole of $\mathrm{Ni}$ is situated at the level of the posterior boundary of $1 / 3$ of the anterior part of $\mathrm{Nh}$, and the anterior pole lies about $500 \mu \mathrm{m}$ to the rear of the anterior pole of nucleus olivaris inferior. The length of this nucleus is about $6 \mathrm{~mm}$.

The posterior and central sections of $\mathrm{Ni}$ are adjacent on the dorsomedial side to $\mathrm{Np}$, and on the ventromedial side to $\mathrm{Nh}$. The anterior part runs upwards and lies medially and slightly ventrally from $\mathrm{Np}$, and dorsally from $\mathrm{Nh}$. In cross-section $\mathrm{Ni}$ consists of a group of cells similar to an elongated triangle, the base of which is directed laterally.

$\mathrm{Ni}$ is formed of rounded cells measuring $15-20 \mu \mathrm{m}$ and fusiform cells measuring $20-30 \mu \mathrm{m}$ along the long axis. The cells contain a large light-staining nucleus with a centrally positioned nucleolus and considerable amount of tigroid substance.

Nucleus praepositus Marburgi, Nm (Photos. 3, 14)

$\mathrm{Nm}$ is situated in the dorsal part of the floor of ventricle IV. The posterior pole of $\mathrm{Nm}$ lies at a small distance forwards from the po- 
sterior pole of $\mathrm{Ni}$. The anterior pole of the nucleus is situated slightly forwards of the analogical pole of $\mathrm{Np}$. Length of $\mathrm{Nm}$ is about $7.5 \mathrm{~mm}$. In cross-sections $\mathrm{Nm}$ appears as a fairly large round cluster of cells. On the lateral side it is adjacent to $\mathrm{Ni}$, and on the ventral-lateral side to $\mathrm{Nh}$.

$\mathrm{Nm}$ is formed of fusiform cells measuring $45-50 \mu \mathrm{m}$ along the long axis, rounded cells measuring $25-30 \mu \mathrm{m}$ and a small number of multipolar cells measuring $15-20 \mu \mathrm{m}$. The cells contain a large, light-staining nucleus and numerous large gains of tigroid substance.

Nucleus paramedianus dorsalis s. Jacobsoni, Nd (Photos. 3, 15)

$\mathrm{Nd}$ lies on the floor of ventricle IV, in the immediate vicinity of the raphe. The posterior pole of $\mathrm{Nd}$ appears at a slight distance forwards from the posterior pole of $\mathrm{Nm}$, while the anterior pole disappears in the rear of the anterior pole of $\mathrm{Nh}$. Nd is about $1,2 \mathrm{~mm}$ in length.

In cross-sections $\mathrm{Nd}$ is irregular in shape, and is formed of a few cells (from 2 to 5 in a cross-section) arranged on the ventromedial side of $\mathrm{Nm}$. Nd is formed of fusiform cells measuring $25-35 \mu \mathrm{m}$ along the long axis. The cells contain a light-staining nucleus with a distinct nucleolus and a few grains of tigroid matter.

Nucleus parasympathicus dorsalis nn. IX et X, Np (Photos. 2, 16)

$\mathrm{Np}$ is situated in the closed part of medulla oblongata and on the floor of ventricle IV, where $4 / 7$ of the anterior parts of $\mathrm{Np}$ lie. The posterior pole of $\mathrm{Np}$ lies slightly forwards of the anterior pole of Nac, and the anterior pole disappears slightly to the rear of the anterior pole of $\mathrm{Nm}$. Np is about $17 \mathrm{~mm}$ in length.

In the extraventricular part of medulla oblongata this nucleus appears in cross-sections as a horizontal oval situated on the dorsolateral side of cc, above Nh. On the floor of ventricle IV in cross-sections Np takes on the shape of a rounded group of cells which gradually shifts laterally towards the anterior and lies on the dorsal side of $\mathrm{Ni}$.

$\mathrm{Np}$ is formed fusiform cells measuring $40-80 \mu \mathrm{m}$ and rounded cells measuring $25-35 \mu \mathrm{m}$. In the posterior segment there are a few rounded cells, but their number increases in the anterior part of $\mathrm{Np}$. The cells have a large light-staining nucleus with a distinct nucleolus and large amount of coarse-grained tigroid substance.

$$
\text { Nucleus ambiguus, Na (Photos. 4, 17) }
$$

$\mathrm{Na}$ is situated in the extraventricular part of medulla oblongata (about 5/8 of the posterior parts) and on the floor of ventricle IV (about $3 / 8$ of the anterior parts). The posterior pole of $\mathrm{Na}$ is situated about $2.7 \mathrm{~mm}$ to the re of the posterior pole of nucleus olivaris inferior, 
while the anterior pole disappears about $2.4 \mathrm{~mm}$ to the rear of the anterior pole of nucleus olivaris inferior. $\mathrm{Na}$ is about $16 \mathrm{~mm}$ in length.

The posterior part of $\mathrm{Na}$ lies ventrally and laterally. from $\mathrm{Nh}$ and dorsally and laterally from nucleus olivaris inferior, the distance between $\mathrm{Na}$ and the nuclei referred to being approximately equal, Forwards from calamus scriptorius $\mathrm{Na}$ runs in a ventral direction and approaches nucleus olivaris inferior. In cross-sections the posterior part of $\mathrm{Na}$ is a narrow, homogenous group of cells, which is divided in the medial part into two clusters: dorsomedial and ventrolateral. In its anterior segment $\mathrm{Na}$ is again homogeneous, being formed by a group ct oval cells.

$\mathrm{Na}$ is formed of multipolar cells measuring $\leq 0-80 \mu \mathrm{m}$ and a few fusiform cells measuring $30-40 \mu \mathrm{m}$ along the long axis. The cells contain a light-staining nucleus with a distinct nucleolus and numerous coarse grains of tigroid substance.

\section{Nucleus $n$. facialis, Nf (Photos. 5, 18)}

$\mathrm{Nf}$ lies on the floor of ventricle IV. Its posterior pole appears about $2.4 \mathrm{~mm}$ to the rear of the anterior pole of nucleus olivaris inferior, while the anterior pole disappears about $1.8 \mathrm{~mm}$ forwards from the posterior pole of nucleus olivaris superior. $\mathrm{Nf}$ is about $12.5 \mathrm{~mm}$ in length.

In cross-sections the posterior part of $\mathrm{Nf}$ is a homogeneous small cluster of cells, the size of which quickly increases in a forwards direction. In the medial part, from $1 / 4$ of the posterior to $1 / 4$ of the anterior part, $\mathrm{Nf}$ divides into three groups of cells: medial, median and lateral. The medial group divides for a short distance into the dorsal and ventral parts. The lateral group divides in a similar way. The anterior part of $\mathrm{Nf}$ is homogeneous and forms a large oval group of cells.

The anterior and posterior parts of $\mathrm{Nf}$ and the medial and lateral groups are formed of multipolar cells measuring $60-80 \mu \mathrm{m}$ and a few rounded cells measuring $30-35 \mu \mathrm{m}$. The cells contain a large light -staining nucleus with a distinct nucleolus and a large amount of coarse-grained tigroid substance.

\section{Nucleus n. abducentis. $\mathrm{Nb}$ (Photos. 6, 19)}

$\mathrm{Nb}$ in the European bison lies on the floor of ventricle IV, laterally from the geniculum of nerve VII. The posterior pole of $\mathrm{Nb}$ begins about $480 \mu \mathrm{m}$ to the rear of the posterior pole of nucleus olivaris superior, and the anterior pole is situated about $480 \mu \mathrm{m}$ to the rear of the posterior pole of $\mathrm{Nt}$. $\mathrm{Nb}$ is about $3.7 \mathrm{~mm}$ in length.

The posterior and anterior parts of $\mathrm{Nb}$ seen in cross-section are rounded, but the medial part of $\mathrm{Nb}$ takes on a vertical oval shape. 
The nucleus of $n$. abducentis is formed of multipolar cells measuring $50-75 \mu \mathrm{m}$ and a few rounded cells measuring $30-35 \mu \mathrm{m}$. The cells contain a large light-staining nucleus and numerous grains of tigroid substance.

Nucleus motorius $n$. trigemini, Nt (Photos. 7, 20)

$\mathrm{Nt}$ lies in the anterior part of medulla oblongata and in the pons, where the anterior half of this centre is situated. The posterior pole of $\mathrm{Nt}$ appears about $480 \mu \mathrm{m}$ forwards from the anterior pole of $\mathrm{Nb}$, while the anterior pole disappears about $3 \mathrm{~mm}$ forwards from the anterior pole of nucleus olivaris superior. Nt is about $5,2 \mathrm{~mm}$ in length.

The posterior part of $\mathrm{Nt}$ in cross-sections is a homogeneous cluster of cells. It quickly increases in size in a forwards direction and takes on the shape of an obliquely positioned oval. From $1 / 5$ of the posterior part to $1 / 4$ of the anterior part Nt divides into three groups of cells: dorsal, ventromedial and ventrolateral. The anterior part of $\mathrm{Nt}$ is a homogeneous band of cells.

$\mathrm{Nt}$ consists of multipolar cells measuring $60-75 \mu \mathrm{m}$ and a few rounded cells measuring $15-20 \mu \mathrm{m}$. The cells contain a large lightstaining nucleus with a nucleolus situated centrally and numerous coarse grains of tigroid substance.

Nucleus subtrigeminalis, Ns (Photos. 8, 21)

Ns lies ventrally from $\mathrm{Nt}$. It reaches from $1 / 5$ of the posterior to $2 / 5$ of the anterior parts of Nt. Ns is about $1.1 \mathrm{~mm}$ long. In cross-sections it is shaped like an oblique oval. $\mathrm{Nt}$ is formed of multipolar cells measuring $40-50 \mu \mathrm{m}$ and rounded cells measuring $30-40 \mu \mathrm{m}$. The cells contain a large light-staining nucleus and a large amout of coarse-grained tigroid matter.

\section{DISCUSSION}

The results of studies on the motor nuclei of medulla oblongata in the European bison revealed the similarity of the cytoarchitectonics of these nuclei in this species to those in the cow, pig and horse (Chomiak, 1951), goat (Chomiak, 1954), sheep (Welento, 1956), red deer, roe deer (Fiedoruk, 1975), camel (Strzałka \& Flieger, 1979, 1982) and also the beaver (Galert, Szteyn \& Dynowski, 1978), nutria (Szteyn, 1961, 1962), cat (Highstein et al., 1982) rat (Erzurumlu \& Killackey, 1979; Cooper, 1981; Connors, Sullivan \& Kubb, 1983) and opossum (Hamos \& King, 1980). There are, however, differences in the position and formation of these centres in the European bison as compared with other mammals.

The anterior part of Nac in the European bison is similar to the 
analogical centre in other mammals. There are certain differences in Nacv, the anterior pole of which does not extend in the European bison to the posterior pole of $\mathrm{Nh}$, whereas in the horse (Chomiak, 1951), goat (Chomiak, 1954), roe deer (Fiedoruk, 1975) and nutria (Szteyn, $1961,1962)$ this group in a forwards direction passes into Nh. In the cow (Chomiak, 1951) the ventral group of Nac joins $\mathrm{Na}$, while in the red deer (Fiedoruk, 1975) it is dispersed in the grey matter of the ventral columns of the medulla.

$\mathrm{Nh}$ in the European bison is located in a similar way to that in the pig and horse (Chomiak, 1951) and beaver (Galert, Szteyn x Dynowski, 1978), but is shifted forwards in comparison with Nh in cattle (Goller, 1965), goat (Chomiak, 1954), roe deer (Fiedoruk, 1975), nutria (Szteyn, 1961) and rat (Cooper, 1981). In the European bison Nh in its median. part divides into three groups of cells, which may indicate the more complicated structure of this nucleus in the European bison than in other mammals, in which no such division was found.

Among the nuclei accompanying $\mathrm{Nh}$ the relatively weak development of $\mathrm{Nd}$, which in cross-sections forms a group of a small number $(2-5)$ cells, is remarkable.

$\mathrm{Nr}$ in the European bison is relatively longer than the corresponding centre in the cow and pig (Chomiak, 1951). It lies more forwards than $\mathrm{Nr}$ in the roe deer (Fiedoruk, 1975) and sheep (Welento, 1956), and more to the rear in relation to the position of this nucleus in the goat (Chomiak, 1954) and nutria (Szteyn, 1961).

$\mathrm{Np}$ in the European bison does not exhibit differences in respect of position and length in comparison with other mammals. As in the case of the rat (Connors, Sullivan \& Kubb 1983) it consists of a homogeneous band of cells. In the cow and pig (Chomiak, 1951), goat (Chomiak, 1954) and camel (Strzałka \& Flieger, 1979) Np is divided into groups.

A characteristic feature of $\mathrm{Na}$ in the European bison is its position. In this species it is shifted to the rear in comparison with $\mathrm{Na}$ in the cow and pig (Chomiak, 1951), camel (Strzałka \& Flieger, 1979) and nutria (Szteyn, 1961), and particularly in the red deer and roe deer (Fiedoruk, 1975). The structure of $\mathrm{Na}$ is similar in the European bison and other mammals.

$\mathrm{Nf}$ in the European bison is relatively simple in structure - it is divided, as in the rat (Erzurumlu \& Killackey, 1979) into five groups of cells. In the majority of mammals the structure of $\mathrm{Nf}$ is more complicated, for instance in the pig (Chomiak, 1951), roe deer (Fiedoruk, 1975) and camel (Strzałka \& Flieger, 1982) this nucleus divides into six, and in the horse (Chomiak, 1951) and red deer (Fiedoruk, 1975). even into seven, clustersoof cells. It was only in cattle that Goller 
(1965) and Welento (1965) described only four groups of cells, that is, a smaller number than in the European bison.

$\mathrm{Nb}$ in the European bison lies more dorsal as compared with the corresponding centres in other mammals, on the laterai side of genu of n. VII. In the European bison, as in the nutria (Szteyn 1961, 1962), beaver (Galert, Szteyn \& Dynowski, 1978) and cat (Highstein et al., 1982) $\mathrm{Nb}$ is a homogeneous band of cells, whereas in the cow, pig and horse (Chomiak, 1951), goat (Chomiak, 1954) and red deer and roe deer (Fiedoruk, 1975) $\mathrm{Nb}$ was observed to divide into a dorsal and ventral group of cells.

$\mathrm{Nt}$ in the European bison lies slightly more to the rear than $\mathrm{Nt}$ in the horse (Milart, 1958) and opossum (Hamos \& King, 1980), but far more forwards in relation to this nucleus in cattle (Goller, 1965; Welento 1965), goat, sheep (Welento, 1956) and red deer and roe deer (Fiedoruk, 1975). In other ruminants it is only possible to discern two groups of cells in $\mathrm{Nb}$.

\section{REFERENCES}

1. Chomiak M., 1951: Jądra ruchowe rdzenia przedłużonego krowy, świni i konia. Annls Univ. M. Curie-Skłodowska, C 5: 373-429.

2. Chomiak M., 1954: Topografia i budowa jąder ruchowych rdzenia przedlużonego kozy. Annls Univ. M. Curie-Skłodowska, DD 13: 181-219.

3. Connors N. A., Sullivan J. M. \& Kubb K. S., 1983: An autoradiographic study of the distribution of fibers from the dorsal motor nucleus of the vagus to the digestive tube of the rat. Acta anat., 115: 266-271.

4. Cooper M. H. 1981: Neurons of the hypoglosal nucleus of the rat. Ortolaryngol Head Neck Surg., 89: 10-15.

5. Erzurumlu R. S. \& Killackey H. P., 1979: Efferent conections of the brainstem trigeminal complex with the facial nucleus of the rat. J. comp. Neurol., 188: $75-86$.

6. Fiedoruk J., 1975: Jądra ruchowe rdzenia przedłużonego oraz mostu jeenia i sarny. Pol. Arch. wet., 18: 505-517.

7. Galert D., Szteyn S. \& Dynowski J., 1978: The topography and structure of motor nuclei of medula oblongata in the beaver. Acta theriol., 23: 285-235.

8. Goller H., 1965: Zytoarchitektonik der Medula oblongata des Rindes. Verlag Paul Parey: 1-120, Berlin und Hamburg.

9. Hamos J. E. \& King J. S., 1980: The synaptic organization of the motor nudeus of the trigeminal nerve in the opossum. J. comp. Neurol., 194: 441-463.

10. Highstein S. M., Karabelas A., Baker R. \& McCrea R. A., 1982: Comparison of the morphology of physiologically identified abducens motor and irternuclear neurons in the cat: A light microscopic study emploing the intractllular injections of horseradish peroxidase. J. comp. Neurol., 208: 369-381.

11. Milart Z., 1958: Jądra przedniej części rdzenia przedłużonego i mostu Varola konia. Annls Univ. M. Curie-Skłodowska, DD 13: 63-87.

12. Strzałka B. \& Flieger St., 1979: Budowa i rozmieszczenie przywspółczulıegio i dwuznacznego jądra nerwu językowo-gardłowego oraz błędnego u wielbąda Annls Univ. M. Curie-Skłodowska, DD 34: 25-33. 
13. Strzałka B. \& Flieger St., 1982: Ośrodki nerwowe ruchowe nerwu twarzowego u wielbłąda. Pol. Arch. wet., 23: 145-154.

14. Szteyn St., 1961: Topografia i budowa jąder nerwowych rdzenia przedłużonego nutrii. Część I. Jądra ruchowe rdzenia przedłużonego nutrii. Annls Univ. M. Curie-Skłodowska, DD 16: 119-134.

15. Szteyn St., 1962: Topografia i budowa jąder nerwowych rdzenia przedłużonego nutrii. Część II. Jądra czuciowe rdzenia przedłużonego nutrii. Annls Univ. M. Curie-Sklodowska, DD 17: 21-43.

16. Welento J., 1965: Development of the nerve nuclei of the anterior part of the medula oblongata and pons in the pig. Annls Univ. M. Curie-Skłodowska, DD 20: 139-151.

17. Welento J., 1956: Jądra przedniej części rdzenia przedłużonego i mostu owcy i kozy. Annls Univ. M. Curie-Skłodowska, DD 11: 66-107.

18. Welento J., 1955: The nuclei of the anterior part of the medula oblongata and pons of the brain of cattle. Annls Univ. M. Curie-Skłodowska, DD 10: $185-237$.

19. Zioło I., 1957: Rozwój jąder ruchowych rdzenia przedłużonego świni. Annls Univ. M. Curie-Skłodowska, DD 12: 75-99.

Accepted, April 15, 1985.

Stanisław SZTEYN, Edward SZATKOWSKI i Barbara JATCZAK

\section{JAPQRA RUCHOWE RDZENIA PRZEDEUŻONEGO ŻUBRA}

\section{Streszczenie}

Badania przeprowadzono na rdzeniach przedłużonych czterech żubrów. Materiał cięto na skrawki poprzeczne grubości $15 \mu \mathrm{m}$. Skrawki barwiono metodami Nissla oraz Kluvera i Barrery. Opisano położenie, ukształtowanie oraz budowę komórkową jąder ruchowych rodzenia przedłużonego: nuc. n. accessorii (Nac-ryc. 1. 9, 10), nuc. n. hypoglossi (Nh-ryc. 2, 11), nuc. sublingualis sympathicus (Nr-ryc. 2, 12), nuc. intercalatus Staderini (Ni-ryc. 2, 13), nuc. praepositus Marburgi (Nm-ryc. 3,14 ), nuc. paramedianus dorsalis (Nd-ryc. 3, 15), nuc. parasympathicus dorsalis nn. IX et $X$ (Np-ryc. 2, 16), nuc. ambiguus (Na-ryc. 4, 17), nuc. n. facialis (Nf-ryc. 5, 18), nuc. n. abducentis (Nb-ryc. 6, 19), nuc. motorius n. trigemini (Nt-ryc. 7, 20) i nuc. subtrigeminalis (Ns-ryc. 8, 21). Niektóre z badanych ośrodków nerwowych wykazują $\mathrm{u}$ żubra cechy charakterystyczne nawet. $\mathrm{w}$ porównaniu $\mathrm{z}$ blisko spokrewnionymi ssakami kopytnymi. Nuc. n. accessosrii utworzone jest u żubra z dwóch pasm komórek: grzbietowego i brzusznego, które różnią się od siebie budową komórkową. Nuc. $n$. hypoglosssi jest silnie wykształcone i podzielone na trzy grupy. Spośród jąder towarzyszących nuc. n. hypoglossi najlepiej wykształcone jest nuc. sublingualis sympathicus, a najsłabiej nuc. paramedianus dorsalis. W porównaniu $\mathrm{z}$ innymi przeżuwaczami nuc. ambiguus jest u żubra wyraźnie przesunięte ku tyłowi, a nuc. motorius $n$. trigemini w kierunku przednim. To ostatnie jądro jest u żubra silnie wykształcone i podzielone na trzy grupy komórek. 
cc - central canal

gVII - genu of $n$. facialis

kIV - ventricle IV

Nacd - dorsal group of nuc. n. accessorii

Nacv - ventral group of nuc. n. accessorii

Nadm - dorsomedial group of nuc. ambiguus

$\mathrm{Navl}$ - ventrolateral group of nuc. ambiguus

$\mathrm{Nb}-$ nuc. n. abducentis

$\mathrm{Nd}-$ nuc. paramedianus dorsalis

$\mathrm{Nfi}-$ median group of nuc. $n$. facialis

$\mathrm{Nfl}$ - lateral group of nuc. $n$. facialis

$\mathrm{Nfm}$ - paracentral group of nuc. n. facialis

$\mathrm{Nh}-$ nuc. n. hypoglossi

$\mathrm{Ni}-$ nuc. intercalatus Staderini

$\mathrm{Nm}$ - nuc. praepositus Marburgi

$\mathrm{Np}-$ nuc. parasympathicus dorsalis $n n . \mathrm{IX}$ et $\mathrm{X}$

$\mathrm{Nr}$ - nuc sublingualis sympathicus

Ns - nuc. subtrigeminalis

$\mathrm{Nt}$ - nuc. motorius n. trigemini

Ntd - dorsal group of nuc. motorius n. trigemini

Ntvl - ventrolateral group of nuc. motorius n. trigemini

Ntvm - ventromedial group of nuc. motorius n. trigemini 


\section{EXPLANATION OF PLATES}

Plate VII

Photo. 1. Cross-section of a medulla oblongata at the level of the anterior part of nuc. $n$. accessorii.

Photo. 2. Cross-section of a medulla oblongata at the level of the anterior part of nuc. n. hypoglossi.

Photo. 3. Cross-section of a medulla oblongata at the level of the posterior part of nuc. praepositus Marburgi.

Photo. 4. Cross-section of a medulla oblongata at the level of the median part of nuc. ambiguus.

Photo. 5. Cross-section of a medulla oblongata at the level of the median part of nuc. $n$. facialis.

Photo. 6. Cross-section of a medulla oblongata at the level of the median part of nuc. $n$. abducentis.

Photo. 7. Cross-section of a medulla oblongata at the level of the median part of nuc. motorius n. trigemini.

Photo. 8. Cross-section of a medulla oblongata at the level of the median part of nuc. subtrigeminalis.

\section{Plate VIII}

Photo. 9. Cells of the dorsal group of nuc. n. accessorii.

Photo. 10. Cells of the ventral group of nuc. $n$. accessorii.

Photo. 11. Cells of nuc. n. hypoglossi.

Photo. 12. Cells of nuc. sublingualis sympathicus s. Rolleri.

Photo. 13. Cells of nuc. intercalatus Staderini.

Photo. 14. Cells of nuc. praepositus Marburgi.

Photo. 15. Cells of nuc. paramedianus dorsalis s. Jacobsoni.

Photo. 16. Cells of nuc. parasympathicus dorsalis nn. IX et X.

Photo. 17. Cells of nuc. ambiguus.

Photo. 18. Cells of nuc. n. facialis.

Photo. 19. Cells of nuc. n. abducentis.

Photo. 20. Cells of nuc. motorius n. trigemini

Photo. 20. Cells of nuc. motorius n. trigemini.

Photo 21. Cells of nuc. subtrigeminalis. 


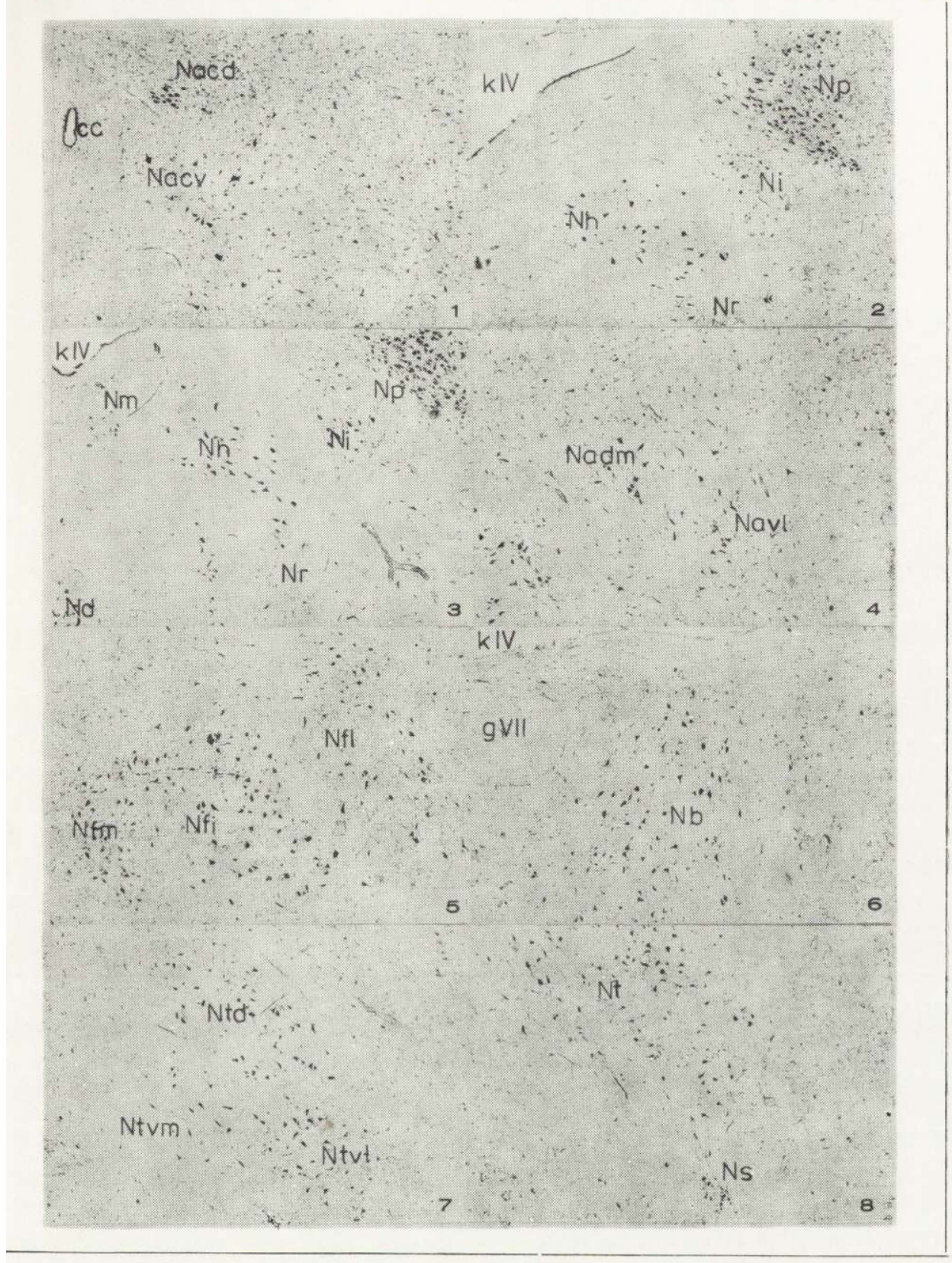

. Szteyn et al.

auctores phot. 

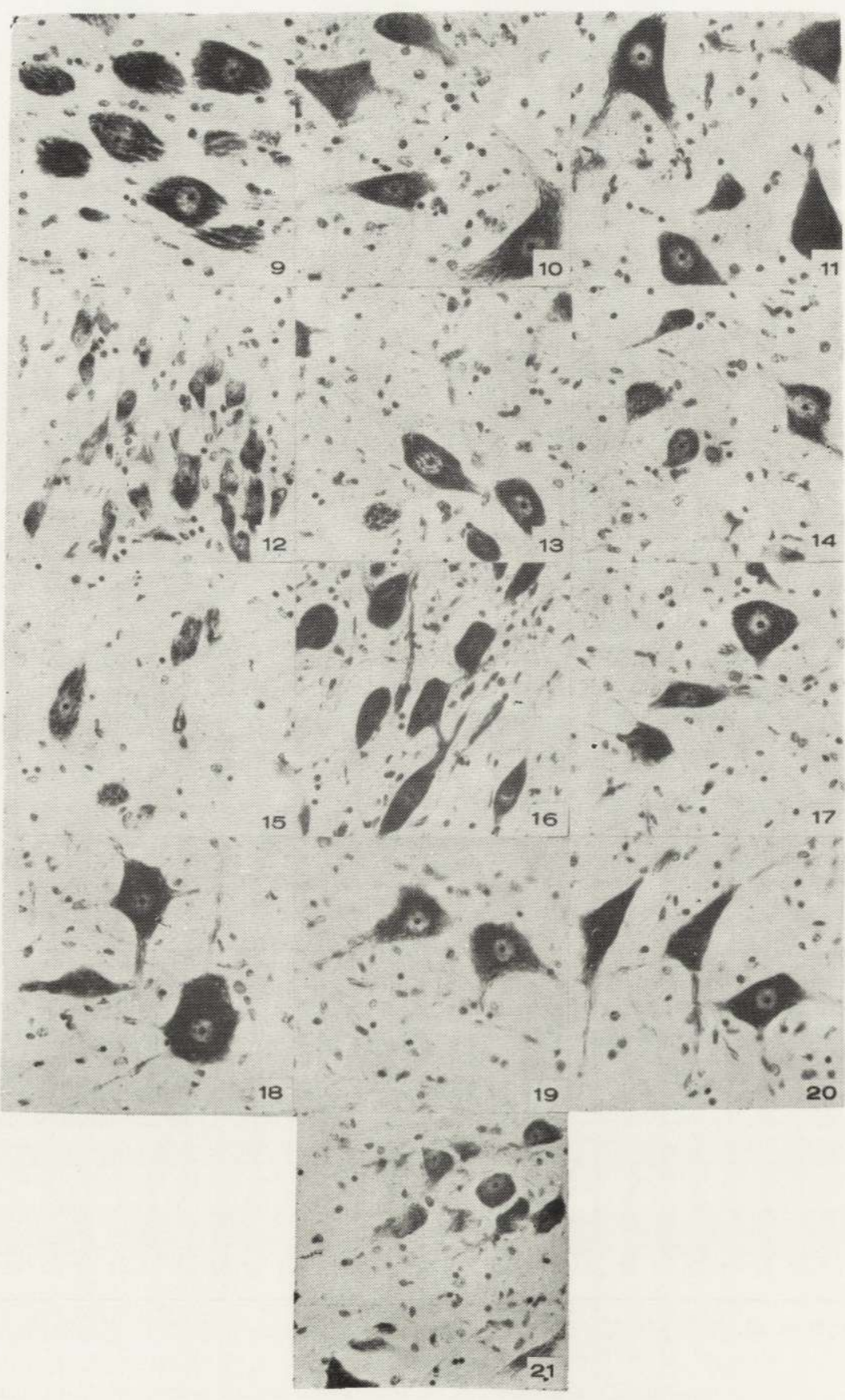

S. Szteyn et al. 